\title{
Revealing the Relationship between Reading Interest and Critical Thinking Skills through Remap GI and Remap Jigsaw
}

\section{Siti Zubaidah}

Prof., Faculty of Mathematic and Natural Science, Universitas Negeri Malang, Indonesia, siti.zubaidah.fmipa@um.ac.id

\author{
Aloysius Duran Corebima \\ Prof., Faculty of Mathematic and Natural Science, Universitas Negeri Malang, \\ Indonesia,durancorebima@gmail.com
}

\section{Susriyati Mahanal}

Faculty of Mathematic and Natural Science, Universitas Negeri Malang, Indonesia

\section{Mistianah}

Department of Biology Education, IKIP Budi Utomo Malang, Indonesia

The aim of this research was to reveal the relationship between student's reading interest and critical thinking skills through Reading Concept Map Group Investigation (Remap GI) and Reading Concept Map Jigsaw (Remap Jigsaw) learning models. To do so, two science classes from first grade of two Senior High Schools in Malang, Indonesia were selected as the participants of the study. They were given the reading interest questionnaire and critical thinking skills essay test after thought by two different learning models. The obtained data were analyzed through Pearson Product Moment Coefficient of Correlation and doing a statistical regression analysis. The result revealed that there was no correlation between two variables both in Remap GI or Remap Jigsaw class. Because of no correlation between two variables was found, two variables were compared through Remap GI and Remap Jigsaw using descriptive analysis. The finding of this study has some implications for teachers to consider some aspect or skills from students and their relationship with each other. So the teacher can predict what needs to be developed and how to do it.

Keywords: reading interest, critical thinking skills, reading concept map, group investigation, jigsaw

\section{INTRODUCTION}

21st Century became the driving issues of the improvement at all pathways and levels of education sectors to prepare the students (Mahanal, Zubaidah, Bahri, \& Dinnurriya,

Citation: Zubaidah, S., Corebima, A. D., Mahanal, S., \& Mistianah (2018). Revealing the Relationship between Reading Interest and Critical Thinking Skills through Remap GI and Remap Jigsaw. International Journal of Instruction, 11(2), 41-56. https://doi.org/10.12973/iji.2018.1124a 
2016). The 21 st century is indicated by the escalated development of technology and information. The learner has to possess the creativity, collaborative, communication, and critical thinking skills that are essentially to face the future shifts (Fuad, Zubaidah, Mahanal, \& Suarsini, 2017). Critical thinking means that learners can determine a careful judgment in making decisions and resolve problems in daily life. Why do students have to possess critical thinking? Nasirahmadi (2014) summarises some of the reasons from Buskist and Irons (2008) stating that some students may think that their judgment is inferior to that of an authoritative figure, students are accustomed to learning by heart rather than thinking about it, students may undermine the consequences of their decisions, students don't have time to allocate to genuine critical thinking, and finally they lack the basic topical knowledge needed for critical thinking.

In the era of information and knowledge, everyone seeks to develop his expertise by obtaining information and knowledge as much as and as quickly as possible. One of the ways to get information and knowledge is by reading. Therefore, the learning process, including biology learning, should be directed to encourage students to find out the various sources of available information by reading. Reading is the most effective learning activities because learners can improve themselves regarding critical thinking, develop new and different perspectives, understand themselves and the world, and interpret events and situations they will face (Karadeniz, 2015).

The education leaders agree if some elements of the ability to think critically are also included in the elements of the ability to read well. Those elements are evaluation, analysis, making inferences, thinking inductive and deductive reasoning (Hawkins, 2012). Reading not only involves the evaluation, analysis, and making conclusions, but also includes reasoning. Nearly four centuries ago, Thorndike stated that the ability to read is an indicator of a person's ability to think and reason. Widuroyekti (2006) explains that reading activity as mind process activation occurs through a series of very complex mental activity. Based on these explanations, it can be said that the process of reading is closely related to the development of thinking factors, including critical thinking.

Reading interest is closely related to critical thinking skills. There are several publications on the relationship between reading interest and critical thinking skills, one of which was done by Aloqaili (2011). Also, there are several examples of research on the relationship of reading interest and critical thinking skills, of which most the dependent variable was critical thinking skills and the independent variable was reading. Research by Hosseini, Khodaei, Sarfallah, and Dolatabadi (2012), examined the relationship between critical thinking, reading, and reading strategies of students majoring in English. In those studies, critical thinking is taken as dependent variable and reading as the independent variable. The results showed a positive relationship between critical thinking and reading comprehension. Students with higher critical thinking ability show better in reading comprehension. Fahim and Kamali (2011) found that learners with the high critical thinking ability have the potential to understand a text that contains difficult words.

Hassani, Rahmany, and Babaei (2013) reported that there was a positive correlation between the critical thinking skills and the ability to read journals. Similarly, Nasirahmadi (2014) 
found that there was a positive correlation between critical thinking skills and reading skills of Iranian language learners. Hawkins (2012) analyzed the relationship between critical thinking skills and reading. He showed a positive relationship between the ability of critical thinking and reading. The more often students spend time to read the book, the greater their critical thinking skills will be. Reading is more than saying what is in the text, reading is thinking. Critical thinking is the ability to explain the ambiguous sentences by making an alternative interpretation, realizing in experience, making a decision and accepting the alternative explanations. Critical thinking is concluded as a process of understanding in reading (Aloqaili, 2011) or the thought process to build understanding (Yu-hui, Li-rong, \& Yue, 2010). Based on several experts' statements previously, it can be concluded that the relationship whether reading can improve the critical thinking skills is related to the components of reading itself.

In respect of the relationship between reading and critical thinking skills, we want to reveal the relationship between the two variables with different learning models. The empowering of reading interest and critical thinking skills may be better if it is done in particular learning models. One of the learning models that had been proved to empower reading interest and critical thinking skills was Reading Concept Map Cooperative Learning, which we used the term Remap Coople as its acronym. Remap Coople is a learning model that requires students to read (reading process) and compose a concept map before going to the classroom, and the learning process in the classroom uses one of the types of cooperative learning models (Zubaidah, 2014). The cooperative learning can be confirmed by grouping strategy, which should focus on how scaffolding and peer-learning will be smoothly run (Baskoro, Corebima, Susilo, Zubaidah, \& Ramli, 2017). This research used the cooperative learning model Group Investigation and Jigsaw type, so the term of learning models that we used are Reading Concept Map Group Investigation (Remap GI) and Reading Concept Map Jigsaw (Remap Jigsaw). The steps of both models followed Pangestuti, Mistianah, Corebima, and Zubaidah (2015) and Mahanal et al. (2016), i.e. (1) the students have to read the related learning materials for next lesson determined by the teacher, (2) the students compose their concept map after reading before going to the classroom, and (3) the learning in the classroom uses cooperative learning GI in one biology class and Jigsaw in another class.

Research on Remap GI had been done by Prasmala (2014) through classroom action research design. The results showed that the application of Remap GI learning model was able to improve critical thinking skills and student learning outcomes in biology learning. Other research concerning Remap GI and Remap Jigsaw had been done by Mistianah, Corebima, and Zubaidah (2015) through experimental research. The results showed that there were significant differences in metacognitive skills and student's learning outcomes on those who were taught by both of Remap GI and Remap Jigsaw. The finding of this study has some implications for teachers to consider some aspects or skills from students and their relationship with each other. So the teacher can predict what needs to be developed and how to do it.

\section{Aims of the Research}

The relationship between reading interest and critical thinking skills, especially in the application of different learning models has less explored yet. Hence, the aim of the 
research was to reveal the relationship between reading interest and critical thinking skills of students through Remap GI and Remap Jigsaw at biology learning. This study was conducted to find an answer to the following questions:

Is there a relationship between student's reading interest and critical thinking skills through Remap GI learning models?

Is there a relationship between student's reading interest and critical thinking skills through Remap Jigsaw learning models?

Is there a difference of relationship between student's reading interest and critical thinking skills through Remap GI and Remap Jigsaw learning models?

\section{METHOD}

\section{Research Design}

This research was correlational research to reveal the relationship between reading interest and critical thinking skills by two kinds of learning models. The biology learning models used in this correlational research were Remap GI and Remap Jigsaw. The obtained data were analyzed through Pearson Product Moment Coefficient of Correlation and doing a statistical regression analysis. The relationship between two variables was conducted through Remap GI and Remap Jigsaw using descriptive analysis.

\section{Population and Sample}

The research was conducted at two Senior High Schools in Malang City, Indonesia. The population of this research was all the students of Senior High School in Malang majoring in science program. The sample of this research was the students majoring in science program during the even semester of the 2014/2016 academic year with the total sample of 59 students. The sample was randomly chosen by consistency test using ANOVA test previously. The consistency test was obtained from the result of national examination on third grade from the students in population. The research was done at two different classes of two different schools with different learning models.

\section{Research Instruments}

The instrument in this research was reading questionnaire that adapted from Gambrell, Palmer, Coding, and Mazzoni (1996); Maldonado and Gonzales (2010); Wanjari and Mahakulkar (2011). The rubric of critical thinking skills embedded with essay test was developed by Zubaidah, Corebima, and Mistianah (2015), as presented in Table 1. The rubric was developed by modifying the Illinois Critical Thinking Essay Test and Guidelines for Scoring Illinois Critical Thinking Essay Test written by Finken and Ennis (1993). The validity and reliability of the rubric had been tested previously, and the results were valid and reliable (not published yet). The descriptor of the critical thinking was developed based on some elements of critical thinking skills as the focus (the focus of the answer), reasoning (reason or idea), organization (the way of thinking, convention (grammar) and integration. The criteria used in determining the student's critical thinking skill order using criteria modified from Finken and Ennis (1993), i.e. (1) were not apparent or less developing (score 0-2), and (2) starting to develop or developing well (score 3-5). 
Table 1

Rubric of critical thinking skills embedded with essay test

\begin{tabular}{|c|c|}
\hline Score/Point & Descriptor \\
\hline 5 & $\begin{array}{l}\text { - All concepts are correct, clear and specific } \\
\text { - All explanations of the answer are correct, clear, specific, supported by strong and right } \\
\text { reason and clear argument } \\
\text { - The way of thinking is good; all concepts are connected each other and integrated } \\
\text { - Good and correctt grammar } \\
\text { - All aspects are apparent; the evidence is good and balanced }\end{array}$ \\
\hline 4 & $\begin{array}{l}\text { - Most of the concepts are right, clear but less specific } \\
\text { - Most of the explanations of the answer are correct, clear but less specific } \\
\text { - The way of thinking is good, most of the concepts are correlated each other and integrated } \\
\text { - The grammar is good and right; there are a few mistakes } \\
\text { - All aspects are apparent, but they are imbalanced }\end{array}$ \\
\hline 3 & $\begin{array}{l}\text { - Small parts of concepts are correct and clear } \\
\text { - Small parts of the explanation of the answer are correct, clear but the argument is unclear } \\
\text { - The way of thinking is good enough, a small part of concepts are correlated each other } \\
\text { - The grammar is good enough; there are some mistakes of spelling } \\
\text { - Most of the apparent concepts are right }\end{array}$ \\
\hline 2 & $\begin{array}{l}\text { - The concepts are less focus or exaggerating or doubting } \\
\text { - The explanations of the answer are not supporting } \\
\text { - The way of thinking is less good; the concepts are not correlated each other } \\
\text { - The grammar is good; the sentences are incomplete } \\
\text { - A small part of the concept looks right }\end{array}$ \\
\hline 1 & $\begin{array}{l}\text { - All concepts are wrong or insufficient } \\
\text { - The reason is wrong } \\
\text { - The way of thinking is not good } \\
\text { - The grammar is not good } \\
\text { - All aspects are insufficient }\end{array}$ \\
\hline 0 & - There is no answer, or the answer is wrong \\
\hline
\end{tabular}

(Source: Zubaidah, et al., 2015 modified from Finken \& Ennis, 1993)

\section{Data Collection and Analysis}

In order to see whether there is a statistically significant relationship between reading interest and critical thinking skills of students through Remap GI and Remap Jigsaw, Pearson Product Moment Coefficient of Correlation was used after gathering the student raw score on the two tests.

Before analyzing the correlation between two variables, the prerequisite test was conducted related to the data normality using Kolmogorov-Smirnov test. KolmogorovSmirnov test was applied to the number of data which was bigger than 50 (Wright, 2006). The normality test for reading interest and critical thinking data through Remap GI result presented that reading interest and critical thinking skills have a constant significance level by 0.555 and 0.986 at the 0.05 significance level (Table 2). It means that the data of students' reading interest and critical thinking skills taught by Remap GI was normally distributed. 
Table 2

The result of normality test on Remap GI by using One-Sample Kolmogorov-Smirnov Test

\begin{tabular}{|c|c|c|c|}
\hline & & Reading Interest & Critical Thinking Skill Class GI \\
\hline $\mathrm{N}$ & & 26 & 26 \\
\hline \multirow[t]{2}{*}{ Normal Parameter ${ }^{\mathrm{a}, \mathrm{b}}$} & Mean & 2.5646 & 40,8973 \\
\hline & Std. Deviation & 8.08522 & 7.26209 \\
\hline Most Extreme & Absolute & .156 & .089 \\
\hline \multirow[t]{2}{*}{ Differences } & Positive & .123 & .089 \\
\hline & Negative & -.156 & -.072 \\
\hline Kolmogorov-Smirnov Z & & .794 & .456 \\
\hline Asymp. Sig. (2-tailed) & & .555 & .986 \\
\hline
\end{tabular}

a. Test distribution is Normal

b. Calculated from data

The normality test for reading interest and critical thinking data conducted through Remap Jigsaw result presented that reading interest and critical thinking skills have a constant significance level by 0.279 and 0.060 at the 0.05 significance level (Table 3 ). It means that the data of students' reading interest and critical thinking skills taught by Remap Jigsaw was normally distributed.

Table 3

The result of normality test on Remap Jigsaw use One-Sample Kolmogorov-Smirnov Test

\begin{tabular}{|c|c|c|c|}
\hline & & Reading Interest & Critical Thinking Skill Class Jigsaw \\
\hline $\mathrm{N}$ & & 33 & 33 \\
\hline \multirow[t]{2}{*}{ Normal Parameter a,b } & Mean & .7567 & 8.4176 \\
\hline & Std. & 8.29715 & 12.07584 \\
\hline Most Extreme & Deviation & .173 & .230 \\
\hline \multirow[t]{2}{*}{ Differences } & Absolute & .173 & .138 \\
\hline & Positive & -.161 & -.230 \\
\hline Kolmogorov-Smirnov Z & Negative & .992 & 1.323 \\
\hline Asymp. Sig. (2-tailed) & & 279 & .060 \\
\hline
\end{tabular}

a. Test distribution is Normal

b. Calculated from data

The obtained data were analyzed through Pearson Product Moment Coefficient of Correlation and doing a statistical regression analysis. The relationship between two variables was carried out through Remap GI and Remap Jigsaw using descriptive analysis.

\section{FINDINGS}

To answer the first question of the study, Pearson Product Moment Coefficient of Correlation was used to investigate the correlation or go-togetherness of student's reading interest and critical thinking skills through Remap GI learning models. Table 4 demonstrates the significance of such correlation through Remap GI learning models. 
Table 4

The relationship between reading interest and critical thinking skills on Remap GI

\begin{tabular}{llll}
\hline & & Correlations & \\
\hline & & Critical Thinking Class GI & Reading Interest \\
\hline Pearson & Critical thinking Class GI & 1.000 & .114 \\
Correlation & Reading Interest & .114 & 1.000 \\
\hline Sig. (1- & Critical thinking Class GI &. & .290 \\
tailed) & Reading Interest & .290 &. \\
\hline $\mathrm{N}$ & Critical thinking Class GI & 26 & 26 \\
& Reading Interest & 26 & 26 \\
\hline
\end{tabular}

Based on the analysis of the correlation of reading interest toward critical thinking skills of students taught by Remap GI, the significance value obtained was $0.290>0.05$. It can be concluded that the null hypothesis was accepted. It means that there was no correlation between reading interest and critical thinking skills through Remap GI.

Table 5 demonstrates the correlation of student's reading interest and critical thinking skills through Remap Jigsaw, which can answer the second question of this study; Pearson Product Moment Coefficient of Correlation was also used to investigate the significance of such correlation.

Table 5

The correlation between reading interest and critical thinking skills through Remap Jigsaw

\begin{tabular}{llll}
\hline \multicolumn{4}{c}{ Correlations } \\
\hline Pearson & Critical thinking of Jigsaw & Critical Thinking & Reading Interest \\
Correlation & ClassReading Interest & 1.000 & .080 \\
\hline Sig. (1-tailed) & Critical thinking of Jigsaw Class & .080 & 1.000 \\
& Reading Interest & .329 & .329 \\
\hline $\mathrm{N}$ & Critical thinking of Jigsaw Class & 33 &. \\
& Reading Interest & 33 & 33 \\
\hline
\end{tabular}

Based on the analysis of the correlation between reading interest and critical thinking skills conducted through Remap GI and Remap Jigsaw, the significance value obtained was $0.329>0.05$. It can be concluded that the null hypothesis was accepted. It means that there was no relationship between reading interest and critical thinking skills in biology learning based on Remap Jigsaw.

To analyze the data further, regression analysis was conducted using SPSS (statistical package for social sciences) and showed in Table 6.

Table 6

Model Summary ${ }^{\mathrm{b}}$ : R Square table for students' scores on reading interest as the predictor of students' critical thinking skills

\begin{tabular}{cccccc}
\hline $\begin{array}{c}\text { Mode } \\
1\end{array}$ & $\mathrm{R}$ & R Square & $\begin{array}{c}\text { Adjusted R } \\
\text { Square }\end{array}$ & $\begin{array}{c}\text { Std. Error of } \\
\text { Estimate }\end{array}$ & Durbin-Watson \\
\hline 1 & $.144^{\mathrm{a}}$ & .013 & -.028 & 7.36373 & 1.926 \\
\hline
\end{tabular}

a. Predictors: (Constant), Reading Interest

b. Dependent Variable: Critical Thinking Class GI 


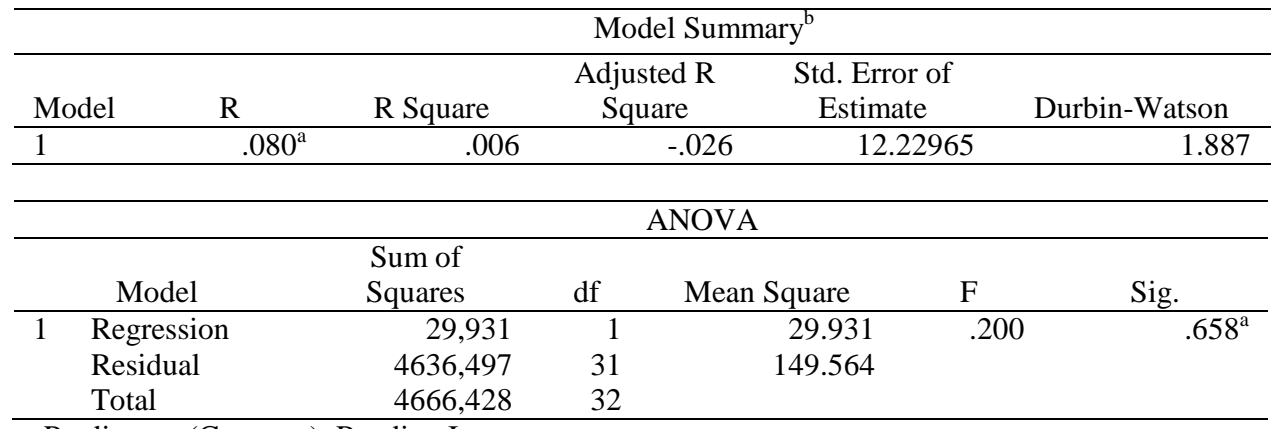

a. Predictors: (Constant), Reading Interest

b. Dependent Variable: Critical Thinking of Jigsaw Class

\section{DISCUSSION}

The main concern of this study was to determine whether there was relationship between students's reading interest and critical thinking skills through Remap GI and Remap Jigsaw learning models. Considering our first research question which asked whether there was a relationship between students's reading interest and critical thinking skills through Remap GI, the result of the study revealed that there was no correlation between reading interest and critical thinking skills throug Remap GI.

The second research question which asked whether there was a relationship between students's reading interest and critical thinking skills through Remap Jigsaw, the result of the study revealed that there was no correlation between reading interest and critical thinking skills throug Remap Jigsaw.

The results of this research are not consistent with the results of previous studies. Some researches conducted by Fahim and Kamali (2011), Hosseini et al. (2012), Hawkins (2012), and Nasirahmadi (2014) that examine the relationship between critical thinking and reading skills showed positive correlation between critical thinking and reading. In other researches such as Purba (2013) showed that reading interest has a positive influence on the ability to think critically.

These results are also not consistent with the review of the theory suggesting that there is a relationship between reading and critical thinking skills. According to the review on the theories, the relationship between reading and critical thinking skills can be explained that by the model of information processing. Based on the study of related literature, there is a strong relationship between reading skills, critical thinking, and prior knowledge. The relationship is interdependent or mutually dependent that is the prior knowledge serves as the basis or foundation of critical thinking and making conclusions. Thinking critically and making conclusions can activate someone's prior knowledge. The theory of schema shows how reading can be developed by using the relationship between literacy and critical thinking (Aloqaili, 2011). Reading has a significant influence in the process of developing critical thinking because the reader should recognize patterns in text, match every detail in the patterns, and then connect it with the other text, and give the experience of it. According to Tung and Chang (2009), reading is suitable for an important feature of critical thinking based on the following 
reasons. The first, the mental process of reading requires the ability to think critically. Reading is a complex process that requires the reader to remember, take it back and reflect on their previous experiences or memories to construct the meaning from text. The second, reading material, background, and language in literature help the reader to build a sense of self and the meaning of life gradually with various real-world scenarios.

The difference results of this research with the results of previous studies may be due to several things which will be described further. The first is the "cultural influence" of our learners. Although it has been assumed that the students had answered the questionnaire reasonably, seemingly they tended to answer by referring to what they expect but not based on their reality. As a consequence, the result of reading interest questionnaire tended to be very good. The second, a lack of correlation between reading and critical thinking skills may be caused partly by using inventory which is not always effective for gathering data. It could happen because students looked in a hurry and were not wishfully when they were filling out the questionnaires. This result is consistent with Corebima (2009), which examined the use of MAI (Metacognitive Awareness Inventory) or questionnaire on metacognitive awareness and MSI (Metacognitive Skills Inventory) or questionnaire on metacognitive capabilities in Indonesia. Corebima (2009) stated that the MAI and MSI were not suitable for measuring student's metacognitive ability of Indonesian students. This thing happened because there was an extreme decrease in the scores of MAI and MSI occurring in the elementary school up to high school investigated.

The use of questionnaires also indicated the ineffectiveness of the research resulted by Schraw and Dennison (1994) and Corliss (2005) in Corebima (2009) that tested the validity by comparing the scores MAI with a score of metacognitive of other measuring instruments. The results showed that there was no significant relationship between MAI score and score of the other metacognitive measurements. Besides, the ineffectiveness of the questionnaire is also indicated in the research results conducted by Sumadi (1987), which examined the relationship between reading interest, language talent and student's reading comprehension achievement in Senior High School in Indonesia. The result of those research showed that there was a significant positive correlation between reading interest and the achievement of reading comprehension, one of which may be due to a lack of effectiveness in using the questionnaires.

Several studies also showed the ineffectiveness of the use of the questionnaire including Hardi (2014), Antika (2015), Talakua (2015), and Bahri and Corebima (2015). Hardi (2014) revealed in his research that the value obtained by linear regression coefficient was 0.484 and the value of the reliability of reading on cognitive learning outcomes was $8.6 \%$. Antika (2015) also revealed that the contribution of reading on the cognitive learning outcomes was only $0.4 \%$. The low contribution of reading interest on cognitive learning outcomes in these studies might be caused by the use of less appropriate instruments. Furthermore, Talakua research (2015) showed that the average increase in student's scores on student's character in cooperative class was equal, which might be caused by the use of less effective questionnaires. 
The questionnaire is the most common instruments used to measure variables in education and psychology. However, the use of questionnaires raised concerns about the lack of response bias. Response bias is a systematic tendency to respond the questionnaire items on some fundamental things rather than specific content item (Paulhus, 1991). The data collection process is a complex process in which the possibilities are many differences emerged between the data to be revealed by researchers and the responses of the respondents. The difference is known as response bias. The most common response bias is a response to the expectations of the social, namely the tendency to provide answers that make respondents look good or good. Hasan (2014) found that when students filled out the questionnaire, they conveyed what his hopes, not his realities.

Based on those explanations, it is known that the use of questionnaire has some we aknesses. According to Milne (1999) there are some disadvantages of questionnaire as follows: 1) questionnaire has been standardized so it is impossible to explain each point of question that may confuse students, 2) students are not serious in answering the questions especially when the questionnaire requires a long time to complete and 3) students do not fill out the questionnaire honestly because they did not want to reveal the information or they think that they do not get any benefit by completing the questionnaires.

The absence of a relationship between reading interest and critical thinking skills in this research can also be associated with the formation of the reading interest that takes quite a long time because it can also be influenced by internal and external factors, particularly by socio-psychological factors (Shehu, 2015). Similar to reading interest, the formation process of critical thinking also requires quite a long time. In some studies, the results showed that to improve the ability of critical thinking takes more than one semester (Yang \& Chou, 2008). During the learning process, the students have to go through the acquisition process by making inferences automatically and undergo the transfer process. The process spends a long time, and it has to go through a lot of practices in developing student's perceptions and attitudes (Tung \& Chang, 2009).

The third research question asked whether there is the difference of relationship between student's reading interest and critical thinking skills through Remap GI and Remap Jigsaw learning models. As the result of this question, no correlation between two variables was found when the relationship between two variables was examined through Remap GI and Remap Jigsaw using descriptive analysis. The descriptive analysis results showed that there was an increase in student's reading interest and critical thinking skills taught by both of learning models, but it was higher in Remap GI class than Remap Jigsaw.

From the descriptive data it was found that the mean score of student's reading interest and critical thinking skills after thought Remap GI were 74.68 and 47.18. The mean score of student's reading interest and critical thinking skills after thought Remap Jigsaw were 74.01 and 35.71. The results showed that student's reading interest and critical thinking skills thought by Remap GI were higher than thought by Remap Jigsaw. The differences of reading interest and critical thinking skill scores that taught by two kinds of learning models may be due to some reasons that will be further explained. 
The first stage of Remap GI and Remap Jigsaw models is asking students to read the learning materials given by the teacher to be studied. Through reading activities, students can learn and master various things. Reading is a complex process in which readers are asked to recall, review, and reflect their memory to build an understanding of the text. By reading, they must be able to distinguish between facts and opinions, understand the meaning, look for a correlation of the occurrence or event, understand the details, see many points of view, and apply what they learned from the process in real life. From these processes, the reader is trained to think critically especially to explain, analyze, synthesize, interpret, evaluate, solve problems, argue, and apply (Tung \& Chang, 2009). As Karadeniz (2015) stated, persuading students to become good critical readers to improve their students' reading skills is important. The students should have reading interest and habit.

The second stage of Remap GI and Remap Jigsaw models is composing the concept map. Learning with concept maps will make a meaningful learning and develop critical thinking that will improve the ability to remember the knowledge in the long term (Novak, 1984). A concept map is a cognitive task that requires diverse thought high levels thinking process which consists of assessing and classifying information, recognizing patterns, identifying and prioritizing the main idea, comparing and contrasting, identifying relationships, and doing logical thinking (Kinchin, Hay, \& Adam, 2000). A concept map is also possible as a tool to convert tacit knowledge into explicit knowledge. For instance, by reading particular lesson materials, the students learn from the book or other resources and then they construct concept map, the students convert their tacit knowledge into explicit knowledge in their mind map (Handoko, Nursanti, Harmanto, \& Sutrisno 2016). Those processes require students to elaborate and organize meaningful information that cannot be obtained only by remembering information without understanding the sense and looking for a relationship. The thought process in making the concept map is very closely related to the competence of critical thinking (Binkley et al., 2012; Rosen \& Tager, 2013).

The third stage of Remap GI and Remap Jigsaw models is the implementation of cooperative learning models in the classroom. We implemented GI (Group Investigation) and Jigsaw learning models at two difference biology classes. GI is one of the alternatives of cooperative learning model that can improve critical thinking skills and train students to work cooperatively in the group (Fachrurazi, 2011). This case is consistent with the results of research by Wijayanti, Herlambang, and Slamet (2013) showing that the learning model of GI affects the ability of critical thinking skills of the students in the tenth grade of Senior High School 1 Mejayan in Madiun, Indonesia.

GI can enhance critical thinking skills because this model has the following advantages 1) it allows students to use their capabilities of inquiry which makes them be more intensive in researching, searching, and finding solution of $\operatorname{problem}(\mathrm{s}), 2)$ students who participate in the GI tend to take part in discussion and contribute ideas, 3) it encourages students to participate actively, 4) it allows teachers to be more informal, so that teacher can immediately provide relief, praise, and feedback and 5) it improves student's performance and achievement. The other benefit of this learning model is that it makes students become more focused on thinking to examine and find solutions for the problems that can encourage students to think more critically (Wijayanti et al., 2013).

GI learning model puts much emphasis on active student's participation in determining the topic, investigating problems, analyzing the findings, and presenting the results of 
this research. The model can increase the activity and participation of the students to find their own material (information) with the help of various learning resources such as related books and Internet-based. Reading the various references can directly enrich student's knowledge to encourage their critical thinking skills. Research by Klimoviené, Urboniene, and Barzdziukiene (2006) showed that there was a relationship between cooperative learning and critical thinking. Students who learned through cooperative learning will have the ability of higher critical thinking. Cooperative learning can be used to develop critical thinking because it can create an atmosphere of classes in which there is more fun, the students are able to think and can learn to respect each other.

The results that Remap GI gave higher on student's reading interest and critical thinking skills scores rather than by Remap Jigsaw was, which is consistent with Afifuddin (2008) research. That research showed that GI was more effective than Jigsaw and conventional learning. Cooperative learning can also improve student's learning outcomes. The effectiveness of Jigsaw and GI in biology will be able to develop student's thinking to be more active in mastering and deepening competencies under student's responsibility. The principle of cooperative learning is emphasizing on student's cooperative in mastering and deepening certain subject matter, and then they will teach each other mutually.

\section{CONCLUSION}

Based on the research results, it can be concluded that there was no correlation between two variables both in Remap GI or Remap Jigsaw class. The results were not consistent with the previous researches, due to the questionnaire used was not always effective. Because no correlation between two variables was found, the relationship between two variables was compared through Remap GI and Remap Jigsaw using descriptive analysis. The descriptive analysis results showed that student's reading interest and critical thinking skills thought by Remap GI were higher than thought by Remap Jigsaw. The findings of this study have some implications for teachers to consider some aspects or skills from students and their relationship with each other. So the teacher can predict what needs to be developed and how to do it.

\section{RECOMMENDATIONS}

There is a suggestion to further research, to prevent "cultural influences" or response bias in the use of questionnaires on reading interest, it is necessary to add other measuring instruments which are embedded into the test questions or student's reading task.

\section{ACKNOWLEDGEMENTS}

This research was supported by Directorate of Research and Community Service Ministry of Research and Technology and Higher Education of the Republic of Indonesia - Director General of Research Reinforcement and Development, on research funding with a letter of assignment agreement No. 047/SP2H/LT/DRPM/II/2016 and No. 151/SP2H/LT/DRPM/III/ 2016. 


\section{REFERENCES}

Afifuddin, N. (2008). Pengaruh penggunaan model pembelajaran kooperatif tipe Jigsaw dan Group Investigation (GI) terhadap prestasi belajar biologi ditinjau dari motivasi berprestasi siswa [The effect of cooperative learning models Jigsaw and Group Investigation to the academic achievement seen from students' motivation]. (Thesis). Universitas Sebelas Maret Surakarta, Indonesia.

Aloqaili A. S (2011). The relationship between reading comprehension and critical thinking: A theoritical study. Journal of King Saud University - Languange and Translation, 24, 35-41.

Antika, L. T. (2015). Hubungan antara minat baca, keterampilan metakognitif dan berpikir kritis terhadap hasil belajar kognitif pada pembelajaran biologi berbasis Reading Concept Map TPS [The correlation between reading interest, metacognitive skills, and critical thinking skills on biology learning outcomes through Reading Concept Map Think Pair Share]. (Thesis). Universitas Negeri Malang, Indonesia.

Nasirahmadi, A, 2014. The Relationship between Iranian Language Learners Critical Thingking Ability and Their Reading Comprehension Achievement. International Journal of Research Studies in Language Learning, 3(7): 15-27.

Bahri, A. \& Corebima A. D. (2015). The contribution of learning motivation and metacognitive skill on cognitive learning outcome of students within different learning strategies. Journal of Baltic Science Education, 14, 487-500.

Baskoro, A.P., Corebima, D., Susilo, H., Zubaidah, S. \& Ramli, M. (2017). Closing the Science Process Skills Gap between Students with High and Low Level Academic Achievement. Journal of Baltic Science Education, 16(2), 266-277.

Binkley, M., Erstad, O., Herman, J., Raizen, S., Ripley, M., Miller-Ricci, M., \& Rumble, M. (2012). Defining twenty first century skills. In P. Griffin, B. McGaw \& E. Care (Eds.), Assessment and Teaching of 21st Century Skills. Dordrecht: Springer, pp. 17-66.

Corebima, A. D. (2009, November). Metacognitive skills measurement integrated in achievement test. Paper presented at COSMED, RESCAM, Penang, Malaysia.

Fachrurazi. (2011). Penerapan pembelajaran berbasis masalah untuk meningkatkan kemampuan berpikir kritis dan komunikasi matematis siswa Sekolah Dasar [Implementation problem based learning to improve critical thinking skills and mathematics communication skills in Elementary Schools]. Retrieved from http://jurnal.upi.edu/file/8-Fachrurazi.pdf.

Fahim, M., Kamali, Z. (2011). The relationship between critical thinking ability of iranian EFL learners and their resilience level facing unfamiliar vocabulary items in reading. Journal of Language Teaching and Research, 2, 101-114.

Finken M, \& Ennis RH 1993. Illinois critical thinking essay test. Illinois critical thinking project. Champaign: University of Illionis. 
Fuad, N. M., Zubaidah, S., Mahanal, S. \& Suarsini, E. (2017). Improving junior high schools' critical thinking skills based on test three different models of learning. International Journal of Instruction, 10(1), 101-116.

Gambrell, L., Palmer, B. M., Codling, R. M., \& Mazzoni, S. A. (1996). Assessing motivation to read. The Reading Teacher, 49, 518-533.

Handoko, F., Nursanti, E., Harmanto, D., \& Sutriono, (2016). The role of tacit and codified knowledge within technology transfer program on technology adaptation. ARPN Journal of Engineering and Applied Sciences. 11(8), 5275-5282.

Hardi (2014). The effect of reading interests of books toward student learning outcomes BKK accounting. Retrieved from http://download.portalgaruda.org/article.php.

Hasan, A. (2014). Implementasi model pembelajaran Reading Map Student Teams Achievement Divisions untuk meningkatkan kemampuan berpikir kritis dan hasil belajar biologi peserta didik kelas X IPA SMA Insan Cendekia Shalahudin Malang [The implementation of Reading Map Student Teams Achievement Divisions to improve critical thinking skills and learning outcomes first grade Insan Cendekia Shalahudin Senior High School in Malang, Indonesia]. (Thesis). Universitas Negeri Malang, Indonesia.

Hassani, M. T, Rahmany, I., \& Babaei, M. (2013). The relationship between Iranian EFL learners' critical thinking and reading comprehension performance in journalistic texts. Theory and Practice in Language Studies, 3(10), 1873-1878.

Hawkins, K. T. (2012). Thinking and reading among college undergraduates: An examination of the relationship between critical thinking skills and voluntary reading. (Dissertations). University of Tennessee.

Hosseini, E., Khodaei, F. B., Sarfallah, S., Dolatabadi, H. R. (2012). Exploring the relationship between critical thinking, reading comprehension and reading strategies of English University students. World Applied Sciences Journal, 17, 1356-1364.

Karadeniz, A. (2015). An examination of critical reading self-efficacy perceptions among the students of the faculty of education over different variables. Anthropologist, 22, 167-175.

Kinchin, I. M., Hay, D. B., \& Adams, A. (2000). How a qualitative approach to concept map analysis can be used to aid learning by illustrating patterns of conceptual development. Educational Research, 42, 43-57.

Klimovienè, G., Urbonienè, J., Barzdžiukienè, R. (2006). Developing critical thinking through cooperative learning. Studies about Languages, 9, 77-84.

Mahanal, S., Zubaidah, S., Bahri, A., \& Dinnurriya, M. S. (2016). Improving students' critical thinking skills through Remap NHT in biology classroom. Asia-Pacific Forum on Science Learning and Teaching, 17(2).

Maldonado, J. L. \& Gonzales, E. (2010). Reading: Gateway to learning. Texas: Laredo Community College Texas. 
McMillan, J. H. (1996). Educational research: Fundamentals to consumer. New York: Harper Collins Colleges Publisher.

Milne, J. (1999). Questionnaires: Some advantages and disadvantages. Retrieved from http://www.icbl.hw.ac.uk/ltdi/cookbook/info_questionnaires/printable.pdf.

Mistianah, Corebima, A. D., \& Zubaidah, S. (2015). Perbedaan keterampilan metakognitif dan hasil belajar biologi antara siswa yang diberi model pembelajaran Reading Concept Map GI dengan Reading Concept Map Jigsaw di SMA Negeri Kota Malang [The differences of metacognitive skills and students learning outcomes who taught by Reading Concept Map GI and Reading Concept Map Jigsaw in Senior High School Malang, Indonesia]. Proceedings of the Conference of the National Biology Education, Universitas Ahmad Dahlan, Indonesia.

Nasirahmadi, A. (2014). The relationship between Iranian language learners' critical thinking ability and their reading comprehension achievement. International Journal of Research Studies in Language Learning, 3, 15-27.

Novak, Y. (1984). Meaningful learning: The essential factor for conceptual change in limited or inappropriate propositional hierarchies leading to empowerment of learners. Science Education, 86, 548-571.

Pangestuti A. A., Mistianah, Corebima, A. D., \& Zubaidah. S. (2015). Using remap TGT to improve reading interest of tenth grade student of Laboratory Senior High School State University of Malang. American Journal of Educational Research, 3, 250254.

Paulhus, D. L. (1991). Measurement and control of response bias. In J.P. Robinson, P.R. Shaver, \& L.S. Wrightsman, Measures of Personality and Social Psychology Attitude San Diego, CA: Academic Press, Inc., pp. 17-59.

Prasmala, E. R. (2014). Penerapan model Reading Concept Map Grup Investigation (GI) untuk meningkatkan minat baca, kemampuan berpikir kritis, metakognitif, dan hasil belajar kognitif biologi siswa kelas X SMA Surya Buana Malang [The implementation of Reading Concept Map Group Investigation (GI) to improve reading interest, critical thinking skills, metacognitive and learning outcomes of first grade Surya Buana senior high school in Malang, Indonesia]. (Thesis). Universitas Negeri Malang, Indonesia.

Purba (2013). Pengaruh minat baca terhadap kemampuan berpikir kritis siswa dalam bidang studi ekonomi kelas XI IPS SMAN 17 Medan tahun ajaran 2012/2013 [The effect reading interest on critical thinking skills in second grade of economic class in Senior High School 17 Malang, Indonesia). (Thesis). Universitas Negeri Malang, Indonesia.

Rosen, Y., \& Tager, M. (2013). Evidence-centered concept map as a thinking tool in critical thinking computer-based assessment. Research \& Innovation Network. Pearson Education.

Shehu, I. (2015). Factors that influence students' reading comprehension achievement in the foreign language. Anglisticum Journal, 4(3), 231-235. 
Sumadi. (1987). Hubungan antara minat baca dan bakat bahasa dengan prestasi membaca pemahaman siswa SMA [The correlation of reading interest and language with reading outcomes senior high school student]. (Thesis). Universitas Negeri Malang, Indonesia.

Talakua, C. (2015). Pengaruh model pembelajaran cooperative script dan stad terhadap hasil belajar, kemampuan berpikir kritis, karakter dan retensi siswa SMA di Kota Masohi, Ambon [Effect of Cooperative Script and STAD learning model on learning outcomes, critical thinking skills, character and retency of Senior High Schools students in Masohi, Ambon, Indonesia]. (Thesis). Universitas Negeri Malang, Indonesia.

Tung, C. A. \& Chang, S. Y. (2009). Developing critical thinking through literature reading. Feng Chia Journal of Humanities and Social Sciences, 19, 287-317.

Wanjari, S. \& Mahakulkar, V. (2011). Assesing reading habits of D.Ed. Trainee Teachers. Indian Streams Research Journal, 1, 76-81.

Widuroyekti, B. (2006). Pengembangan kemampuan berpikir melalui pembelajaran membaca kritis di sekolah dasar kelas tinggi [The development of thinking skills based on reading critical learning in elementary school on high class]. Jurnal Didaktika, 1(1), $1-14$.

Wijayanti, W., Herlambang, S., \& Slamet, M. (2013). Pengaruh model pembelajaran Group Investigation (GI) Terhadap Kemampuan Berpikir Kritis Siswa Kelas X SMA Negeri 1 Mejayan Kabupaten Madiun [Effect of Group Investigation learning models on critical thinking skills of first grade Senior High School 1 Mejayan, Madiun, Indonesia]. Retrieved from http://jurnalonline.um.ac.id/ data/artikel/ artikel2405E92B2C971A74C4C2BDB5B72 4F6E4.pdf.

Wright, D. B. (2006). Discovering Statistics Using SPSS. London: SAGE Publication.

Yang, Y. C. \& Chou, H. A. (2008). Beyond critical thinking skills: investigating the relationship between critical thinking skills and dispositions through different online instructional strategies. British Journal of Educational Technology, 39, 666-684.

Yu-hui, L., Li-rong, Z., \& Yue, N. 2010. Application of schema theory in teaching college English reading. Canadian Social Science, 6, 59-65.

Zubaidah, S. (2014). Pemberdayaan keterampilan penemuan dalam scientific approach melalui pembelajaran berbasis Remap Coople [Empowerment the scientific approach discovery skills use Remap Coople learning model]. Proceedings of the Conference of the National Biology Education XI. Universitas Sebelas Maret Indonesia, 1000-1011.

Zubaidah, S., Corebima, A. D., \& Mistianah. (2015). Asesmen berpikir kritis terintegrasi tes essay [Assessment of critical thinking integrated with essay tests]. Proceedings of the Symposium on Biology Education, Jurusan Biologi FKIP Universitas Ahmad Dahlan Yogyakarta, 200-213. 